\title{
THE, VALUE OF HYPOTHERMIA IN SURGERY OF THE ABDOMINAL AORTA
}

\author{
J. A. MCConnell, M.D., W. A. Dodus, † M.D., ANd H. B. Graves, ł M.D., C.M.
}

Moderate hypothermia has been used as an adjunct to anaesthesia and surgery in 54 of the 113 operations on the abdominal aorta performed on 112 patients at The Vancouver General Hospital during the period January 1, 1956, to December 31, 1961. As reported earlier by McKenzie, ${ }^{1}$ hypothermia was felt to be "advantageous with respect to shock tolerance and renal function". and also by Elliot et al.," "to protect the renal tubules" in the cases of ruptured abdominal aortic aneurysms, in whom shock may be present for a prolonged period. Moderate hypothermia itself was felt to have no complications if carefully controlled. With protection of renal function and smooth postoperative recovery as an aim, hypothermia was used with increasing frequency from 1959 to 1961. The purpose of this study is to assess whether patients with hypothermia had a significantly better morbidity and mortality than those operated upon under normal operating room conditions.

\section{Selection of Cases}

The operations were performed by a variety of surgical and anaesthetic teams but in general the techniques were considered similar and comparable. These operations were abdominal aortic aneurysms (ruptured, "acute," and asymptomatic) and thrombosis of the lower aorta (Leriche syndrome) which involved occlusion of the aorta below the level of the renal arteries. Those considered as "hypothermia" cases reached an oesophageal temperature of less than $32.2^{\circ} \mathrm{C}$. $\left(90^{\circ} \mathrm{F}\right.$.). No patients were refused surgery or excluded because of preoperative shock or associated or pre-existing disease.

\section{Results}

In Table I the 113 operations are subdivided into the three appropriate categories under each main division-hypothermia and normothermia. The ruptured aneurysm group includes those with recent active haemorrhage and haematoma formation, while in the elective group are a small number of cases with acute recent symptoms, chiefly pain, but without haematoma or active bleeding.

${ }^{\circ}$ From the Department of Anaesthesiology, The Vancouver General Hospital, and the Medical Faculty, University of British Columbia.

†Clinical Assistant Professor, Department of Surgery, Sub-section Anaesthesia, University of British Columbia Medical School.

$\ddagger$ Clinical Associate Professor, Department of Surgery, Sub-section Anaesthesia, University of British Columbia Medical School. 
TABLE I

Number of Cases in Each Category

\begin{tabular}{|c|c|c|c|c|c|c|}
\hline & \multicolumn{3}{|c|}{ Hypothermia (54) } & \multicolumn{3}{|c|}{ Normothermia (59) } \\
\hline & \multirow{2}{*}{$\begin{array}{c}\text { Thrombosis } \\
\text { of } \\
\text { aorta }\end{array}$} & \multicolumn{2}{|c|}{ Aneurysm } & \multirow{2}{*}{$\begin{array}{c}\text { Thrombosis } \\
\text { of } \\
\text { aorta }\end{array}$} & \multicolumn{2}{|c|}{ Aneurysm } \\
\hline & & Ruptured & Elective & & Ruptured & Elective \\
\hline 1956 & 1 & 0 & 1 & 1 & 2 & 1 \\
\hline 1957 & 1 & 0 & 0 & 4 & 6 & 6 \\
\hline 1958 & 2 & 3 & 1 & \pm & 3 & 11 \\
\hline 1959 & 1 & 4 & 8 & 3 & 3 & 3 \\
\hline 1960 & 3 & 4 & 10 & 1 & 0 & 0 \\
\hline 1961 & 0 & 5 & 10 & 5 & 3 & 3 \\
\hline Total & 8 & 16 & 30 & 18 & 17 & 24 \\
\hline
\end{tabular}

In Figure 1 the age distribution of the 46 hypothermia aneurysm cases is seen to be comparable with the 41 normothermia aneurysm cases, indicating that hypothermia was not selected for older paticnts, who presumably would be poorer surgical risks. The average ages of the aneurysm patients under hypothermia was 66.9 years (ruptured 71.2 years) and normothermia 68.6 years (ruptured 69.4-years), whereas the patients with Leriche syndrome had an average age of 54.9 years. In both groups the male:female ratio was $6: 1$.

The duration of occlusion of the aorta from 25 to 220 minutes with the majority of the cases requiring a period of 60 to 90 minutes.

\section{Blood Transfusion}

The average volume of blood given in the operatirg room for each category is presented in Table II, which shows that about 500 c.c. more was required for the hypothermia cases, suggesting that the blood loss was significantly greater with

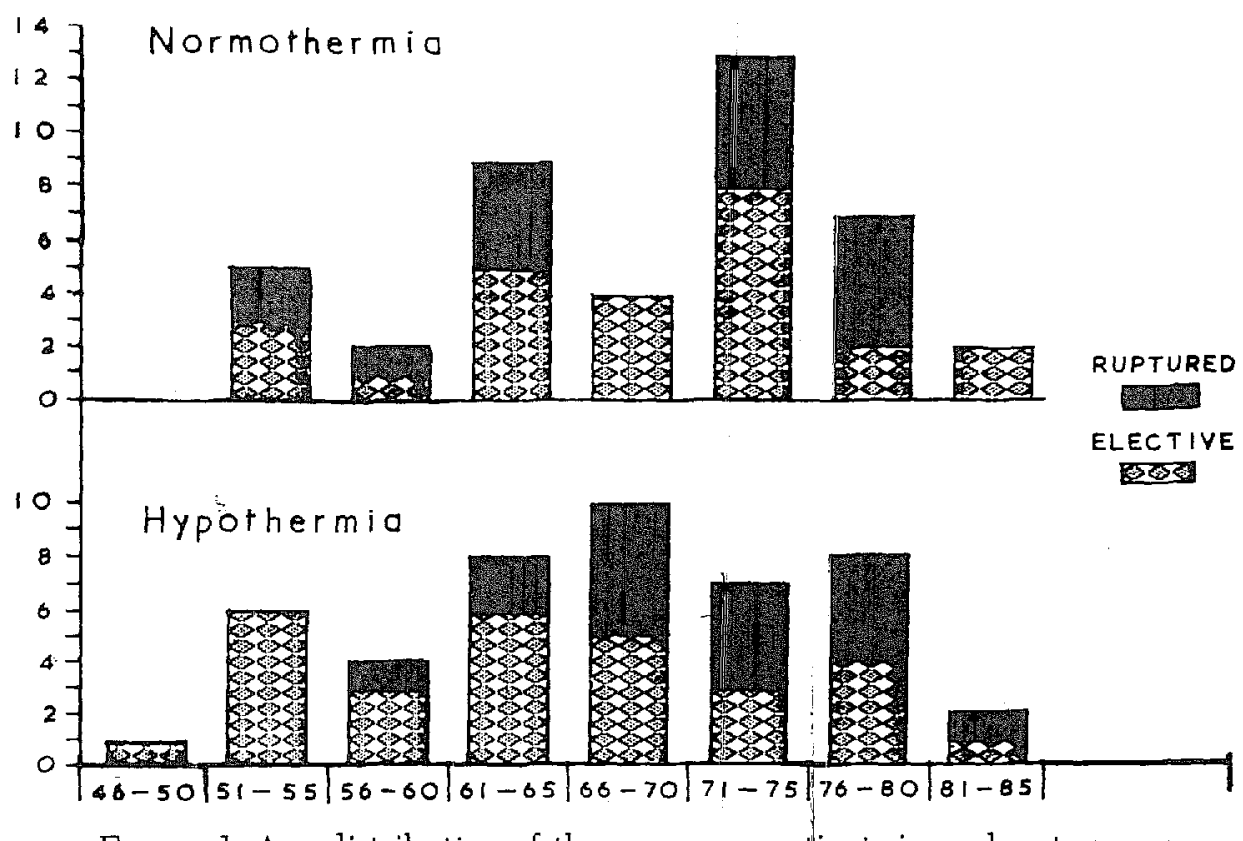

Figure 1. Age distribution of the aneurysm patients in each category. 
TABLE II

\begin{tabular}{lcc}
\multicolumn{3}{c}{$\begin{array}{c}\text { Average Volume (c.c.) of Blood } \\
\text { Given in the Operating Room }\end{array}$} \\
\hline Typombosis of aorta & 2560 & 1280 \\
Tuptured aneurysm & 4690 & 3850 \\
Elective aneurysm & 3280 & 2890 \\
\hline
\end{tabular}

this method. No cases of haemorrhagic diathesis due to hypothermia occurred, but in one normothermia case mild generalized oozing occurred, requiring an additional dose of an antiheparin agent. Heparin 25-50 mg. was injected routinely into the aneurysm prior to clamping.

\section{Temperature}

The lowest temperatures reached, $\rightarrow$ as recorded by oesophageal thermocouple, are presented in 'Table III and it is noted that only 3 cases. reached a temperature lower than $27^{\circ} \mathrm{C}$. $\left(81^{\circ} \mathrm{F} .\right)^{\prime}$, the level generally recommended, ${ }^{*}$ providing a

TABLE III

\begin{tabular}{|c|c|c|}
\hline \multicolumn{3}{|c|}{$\begin{array}{c}\text { FREQUENCY DISTRIBLTION OF LOWEST TEMPERATC LI } \\
\text { RECORDED IN } 53 \text { HYPOTHERIA CASES } \\
\text { (In one case the lowest temperature was nat recorled) }\end{array}$} \\
\hline $\begin{array}{l}89^{\circ} \mathrm{F} . \\
88^{\circ} \mathrm{F} . \\
87^{\circ} \mathrm{F} . \\
86^{\circ} \mathrm{F} .\end{array}$ & 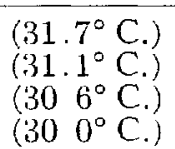 & $\begin{array}{r}3 \\
8 \\
7 \\
10\end{array}$ \\
\hline $\begin{array}{l}85^{\circ} \mathrm{F} . \\
84^{\circ} \mathrm{F} . \\
83^{\circ} \mathrm{F} . \\
82^{\circ} \mathrm{F} .\end{array}$ & 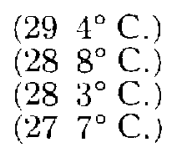 & $\begin{array}{r}11 \\
6 \\
3 \\
2 \\
2\end{array}$ \\
\hline $\begin{array}{l}80^{\circ} \mathrm{F} . \\
76^{\circ} \mathrm{F} .\end{array}$ & $\begin{array}{l}\left(\begin{array}{ll}26 & 8^{\circ} \mathrm{C} .\end{array}\right) \\
\left(2 \pm 4^{\circ} \mathrm{C} .\right)\end{array}$ & $\ddot{2}$ \\
\hline
\end{tabular}

50 per cent reduction in metabolic requirements and safety, as cardiac arrhythmias are uncommon at temperatures above $27^{\circ} \mathrm{C}$. Some observers, however, feel that the lower limit should be $30^{\circ} \mathrm{C}$. $\left(86^{\circ} \mathrm{F}\right.$.), at which level there is a $25-30$ per cent decrease in metabolism. If this standard is accepted, almost half (25) of our cases were cooled excessively.

\section{Complications during the Surgical Procedures}

The complications occurring during the surgical procedures are ahiefly referable to the cardiovascular system. Table IV summarizes those cases showing a period of hypotension in the operating room, and no marked difference between the hypothermic and normothermic groups is apparent.

Cardiac arrhythmias, other than auricular fibrillation, were recorded in only eight cases and all but one of these was in the hypothermia group. In the hypothermia elective aneurysm group one circulatory arrest occurred as a result of 
TABLE IV

Number of Cases in which a Systolic Blood Pressure of Less than 60 mm. Hg Was Recorded for More thas 5 Minutes

\begin{tabular}{|c|c|c|c|c|}
\hline & \multicolumn{2}{|c|}{ Hypothermia } & \multicolumn{2}{|c|}{ Normothermia } \\
\hline & Survivors & $\begin{array}{l}\text { Deaths } \\
\text { in O.R. }\end{array}$ & Survivor & $\begin{array}{l}\text { Death- } \\
\text { in O.K. }\end{array}$ \\
\hline Thrombusis of aortal & - & 一 & 1 & 一 \\
\hline Ruptured aneurs sm & 8 & 2 & 5 & $\bar{j}$ \\
\hline Elective aneury & 11 & 1 & 7 & - \\
\hline Fotal & \multicolumn{2}{|c|}{22} & \multicolumn{2}{|c|}{18} \\
\hline
\end{tabular}

ventricular fibrillation at an oesophageal temperature of $87^{\circ}$ F. ( $30.6^{-}$C. $)$. Resuscitation was successful. Cardiac massage was required in two hypothermia cases but these were not considered arrests associated with the conduct of anaesthesia but rather arrests due to haemorrhage.

\section{Postoperative Complications}

Table V summarizes the postoperative complications (mortality in brackets). There was a significant preponderance of respiratory complications and of postoperative hypotension in the hypothermia group, but these complications did not contribute significantly to the mortality rate. No striking difference was seen between the two groups, and certainly no "protective" eftect of hypothermia is apparent, nor is it seen in the cases demonstrating oliguria (Table VI)..Postoperative peripheral nerve dysfunction was not reported in any patient.

\section{TABLE V}

I\CIDLACL Uh COMPLICATIONS OCCLRKING DL RING IHL. RI:MAIDDER OF THF HOSPITAL STAY (cases which died are recorded in parentheses)

\begin{tabular}{|c|c|c|}
\hline & Hy pothermia & Vormothermirl \\
\hline $\begin{array}{c}\text { Impaired crevilation to legs } \\
\text { Secondary operations for } \\
\text { impaired circulations }\end{array}$ & $5(2)$ & $\overline{7}(3)$ \\
\hline $\begin{array}{l}\text { Legs } \\
\text { Nephrectom }\end{array}$ & $\begin{array}{l}7(t) \\
1(1)\end{array}$ & $8(3)$ \\
\hline $\begin{array}{l}\text { Hypotension in portoperative } \\
\text { recovery room }\end{array}$ & $6(1)$ & - \\
\hline $\begin{array}{l}\text { Pulmonary } \\
\text { Pneumonia } \\
\text { Bronchitis } \\
\text { Aspiration pneunnonicl }\end{array}$ & $\begin{array}{l}6(1) \\
1 \\
-\end{array}$ & $\begin{array}{l}- \\
2 \\
1\end{array}(1)$ \\
\hline $\begin{array}{l}\text { Wound } \\
\text { Evisceration } \\
\text { Infection } \\
\text { Acute parotitis } \\
\text { Small bowel obstruction }\end{array}$ & $\begin{array}{l}2(1) \\
1 \\
1\end{array}$ & $\begin{array}{l}j(1) \\
-- \\
- \\
-\end{array}$ \\
\hline $\begin{array}{l}\text { Oliguria } \\
\text { Mild, } 24 \text { hours } \\
\text { Moderate, }<48 \text { hours } \\
\text { Severe, }>48 \text { hours }\end{array}$ & $\begin{array}{c}1+(2) \\
3 \\
1(1)\end{array}$ & $\begin{array}{r}13(3) \\
13(2) \\
3(2)\end{array}$ \\
\hline Total & $49(1)$ & $+1)$ \\
\hline
\end{tabular}


TABLE VI

Analysis of the Cases Demonstrating Postoperative Oliguria

\begin{tabular}{|c|c|c|c|c|c|c|}
\hline & \multicolumn{3}{|c|}{ Hypothermia } & \multicolumn{3}{|c|}{ Normothermia } \\
\hline & Mild & Moderate & Severe & Mild & Moderate & Severe \\
\hline Thrombosis of aorta & 3 & 1 & 1 & 2 & - & - \\
\hline Ruptured aneurysm & 4 & - & - & 4 & 1 & 2 \\
\hline Elective aneury sm & 7 & 2 & - & 8 & - & - \\
\hline Total & $1 \pm$ & 3 & 1 & 14 & 1 & 2 \\
\hline & & 18 & & & 17 & \\
\hline operative surrivors & & 37 & & & 33 & \\
\hline
\end{tabular}

\section{Deaths}

The mortality rate in hospital of the hypothermia group was 25.9 per cent compared with 28.8 per cent for the normothermic group (Table VII). The operative mortality, that is those deaths occurring during operation or within the first 24 hours postoperatively, is compared (Table VIII) with that occurring during the remainder of the hospital stay. A marked difference in mortality is noted between cases with ruptured aneurysms done under hypothermia (37.7\%) and those done under normothermia (70.6\%). The high mortality for cases with ruptured aneurysms is almost equally divided in both groups between the operative period and the convalescent period.

\section{TABLE VII}

The Chiff Causes of Death in the Six Groups of Cases BASED ON AUTOPSY REPORTS

\begin{tabular}{|c|c|c|c|c|c|c|}
\hline & \multicolumn{3}{|c|}{ Hypothermia } & \multicolumn{3}{|c|}{ Normothermia } \\
\hline & \multirow{2}{*}{$\begin{array}{c}\text { Thrombosis } \\
\text { of } \\
\text { aorta }\end{array}$} & \multicolumn{2}{|c|}{ Aneurysm } & \multirow{2}{*}{$\begin{array}{c}\text { Thrombosis } \\
\text { of } \\
\text { aortat }\end{array}$} & \multicolumn{2}{|c|}{ Aneurysm } \\
\hline & & Ruptured & Elective & & Ruptured & Elective \\
\hline Haemorrhage & & 3 & 2 & & 5 & \\
\hline $\begin{array}{l}\text { Arteriosclerotic } \\
\text { heart disease }\end{array}$ & & 2 & & & 2 & 1 \\
\hline Acute myocardial & & & & & .) & \\
\hline $\begin{array}{l}\text { Arteriosclerosis and } \\
\text { unsuccessful } \\
\text { re-establishnent } \\
\text { circulation }\end{array}$ & it & & & & 2 & $\cdot 2$ \\
\hline $\begin{array}{l}\text { Massive pulmonary } \\
\text { embolism }\end{array}$ & 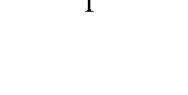 & & 1 & & & \\
\hline $\begin{array}{l}\text { Uraemia-renal } \\
\text { infarction } \\
\text { Pneumonia }\end{array}$ & 1 & & & & 1 & \\
\hline $\begin{array}{l}\text { Staphylococcal } \\
\text { Broncho }\end{array}$ & 1 & 1 & 1 & & 1 & \\
\hline Aspiration & & & & & 1 & \\
\hline $\begin{array}{l}\text { Perforated } \\
\quad \text { duodenal ulcer } \\
\text { No autopsy }\end{array}$ & & & 1 & & & 1 \\
\hline Total & 3 & 6 & 5 & 0 & 12 & 5 \\
\hline Mortality rate & $37.5 \%$ & $37 \%$ & $16.7^{\prime} g$ & $0 \%$ & $706 \%$ & $20.8 \%$ \\
\hline
\end{tabular}


TABLE VIII

\begin{tabular}{|c|c|c|c|c|c|c|}
\hline & \multicolumn{2}{|c|}{$\begin{array}{c}\text { Operative } \\
\text { deaths }\end{array}$} & \multicolumn{2}{|c|}{$\begin{array}{l}\text { Lale } \\
\text { deains }\end{array}$} & \multicolumn{2}{|c|}{ Total } \\
\hline & So. & e.c & No. & $\%$ & No. & $r$ \\
\hline \multicolumn{7}{|l|}{ Hypothermia } \\
\hline Thrombosis of aortal & () & 0 & 3 & 375 & 3 & 375 \\
\hline Ruptured aneurysm & 3 & 188 & 3 & 188 & 6 & $3 \overline{7} . \overline{7}$ \\
\hline Elective aneury sm & 2 & 67 & 3 & 100 & 5 & 167 \\
\hline \multicolumn{7}{|l|}{ Normothermia } \\
\hline Thrombosis of aorta & $\underline{0}$ & 0 & $\underline{0}$ & 0 & 0 & 0 \\
\hline Ruptured aneurysm & $\tau$ & 412 & 5 & $29+$ & 12 & 706 \\
\hline Elective aneury $\mathrm{sm}$ & 1 & +2 & 4 & 166 & 5 & 208 \\
\hline
\end{tabular}

Further analysis of the ruptured aneurysm grcup in an effort to find an explanation in our data for this considerable difference has not revealed any factor of major significance. The two groups are cimparable as to age, and no bias could be detected in a comparison of the preoperative assessment of the two groups. All the patients with ruptured aneurysms came to the operating room with a history of shock of some degree, originating an average of 28 hours previously for the hypothermia and 22.6 hours previously for the normothermia group. Despite resuscitative blood transfusions begun preoperatively for the majority of these cases, irreversible shock was prohably present in two cases in each group. Their omission from the calculations would not appreciably alter the mortality statistics. Omission from the calculations of the one hypothermia case and five normothermia cases that died in the operating room as a result of uncontrollable haemorrhage would alter the mortality rate to 33 per cent for the hypothermia and 58 per cent for the normothermia group.

One might conclude that the use of hypothermia is beneficial in anaesthesia for patients with ruptured aneurysms but this is contrary to the available evidence. Because of the numerous variable factors and the statistically small number of cases, we feel that the use of hypothermia is not of proven value in the treatment of ruptured aneurysms.

\section{Discussion}

Thornton ${ }^{3}$ has provided us with an excellent and complete account of the over-all requirements of anaesthetic management for aortic surgery. Stressed particularly are preoperative assessment and treatment, blood loss replacement, avoidance of respiratory acidosis, and in cast's with hypothermia, a slow rate of rewarming (1-1.5 $\mathrm{C}$. per hour) to avoid hypotension secondary to vasodilation. At his centre (St. Mary's, London) hypothermia was used only for aortic occlusion above the renal arteries, including coarctation in adults.

Wylie and Churchill-Davidson" state that "it is unnecessary to use hypothermia if the aorta is to be clamped below the level of the superior mesenteric and renal arteries, since the tissues below this level can withstand up to two hours or more of reduced blood flow without signs of injury afterwards."

DeBakey's group at Baylor University ${ }^{\widetilde{5}}$ in a 1961 review of 829 abdominal 
aneurysms make no mention of hypothermia. In an earlier plaper, ${ }^{6}$ however, they felt that hypothermia was an important adjunct to protect the spinal cord from ischaemia while dealing with aneurysms of the thoracic aorta which lie between the left common carotid and the level of T.7 vertebra but that "neither shunts nor hypothermia appear to be necessary for lesions below this le:vel."

At the University of Colorado, Swan and Paton ${ }^{7}$ feel that hypothermia is "indicated and of demonstrated merit" in surgery on the descending aorta, and renal and hepatic vessels. Included in their survey are all operations for coarctation of the aorta (having had an early case with paraplegia done without hypothermia). An earlier report from the same centre ${ }^{8}$ stated that the normal abdominal aorta could be cross-clamped below the renal arteries for periods of up to two hours and that in arteriosclerotic obliterative disease the abundance of enlarged collateral vessels prolongs the safe occlusion time.

In a 1961 paper on 150 abdominal aneurysms from the Massachusetts General Hospital, Gryska, Wheeler, and Linton" refer to their anaesthesia as "oxygen, curare and blood" and do not apparently use hypothermia. Essentially similar are recent reports from the University of Michigan, ${ }^{10}$ the .New York Hospital, ${ }^{11}$ and the Mayo Clinic, ${ }^{12}$ in which hypothermia is not specifically mentioned. It was used in only 1 case of 37 abdominal aortic occlusions at the George Washington School of Medicine, ${ }^{13}$ and this paper questions its use even in aortic arch lesions because of the high incidence of cardiac irregularities.

Hypothermia as an anesthetic adjunct has been advocated frequently for "poorrisk" patients ${ }^{14,15,16}$ and for shock, so as to prevent the response to stress, lower the metabolism, and decrease the anaesthetic requirements. This indication is felt by some authors to be unsettled ${ }^{7}$ and the relative lack of new literature on the subject is interpreted by others ${ }^{17}$ as a failure of hypothermia to hold a prominent place. Most authorities are opposed, as for example Lucas, ${ }_{18}^{18}$ who feels that it is "doubtful whether the technique is justified," and Lewis, ${ }^{19}$ who states that "poorrisk patients undergoing major surgery, should probably not be cooled, though an exception might be made for patients with poor liver function who are to undergo porta-caval shunts."

The opinions as to its use in shock are even more dogmatic: Lewis states that "patients suffering from haemorrhagic or traumatic shock are not candidates for hypothermia." This is the conclusion reached by Little, ${ }^{20}$ who reviewed the extensive literature up to 1959, and also by Stephen and Dent ${ }^{21}$ in a recent review.

This conclusion is based on fairly strong experimental evidence. It has been demonstrated that following the establishment of hypothermia there is a depression of ACTH and adrenal cortical secretions. ${ }^{20}$ There is a prompt return of adrenal activity upon rewarming, and, indeed, there may be overactivity during recovery. ${ }^{22}$ Recovery from prolonged hypothermia is associated with an increased secretion of cortical steroids, greater than after operation alone. ${ }^{22}$ Two carefully controlled investigations at the University of Colorado ${ }^{23,24}$ proved that when a single acute haemorrhage is employed to produce shock experimentally, hypothermia exerts a decidedly deleterious effect. The investigators felt that their study "cast doubt upon the rationale" of the use of hypothermia as a method of treatment of haemorrhagic shock. In a study of experimental coronary occlusion ${ }^{25}$ hypothermia was found to be disadvantageous and the authors further stated 
that its use in "poor-risk" patients was "fraught with danger if coronary arterial insufficiency already exists, whether from organic changes in the coronary arterial tree or from diminished filling due to haemorrhage or shock."

In reviewing the recent literature on this subject there are a number of interesting and partly unsolved problems which indicate the many factors that must be considered in a statistical analysis such as ours. These problems may be discussed under the headings: ( $a$ ) problems associated with hypotension, (b) problems of postoperative depression of renal function, $(c)$ problems associated with hypothermia.

\section{(a) Problems Associated with Hypotension}

A period of hypotension, often severe, is commonly seen on release of the aortic clamps. Indeed, in the data presented in Table IV, the period of hypotension seen in 40 of our 113 cases occurred mainly at this time. The chief mechanism producing the blood pressure fall is haemodynamic ${ }^{2 d}$ since, following any circulatory occlusion, a period of reactive hyperaemia occurs, whose extent can be diminished by cooling but only if the vascular occlusion is of less than 30 minutes' duration. With aortic cross-clamping, a very large vascular bed allows pooling of several pints of blood and a consequent reduction in venous return.

Other factors, which must be considered at the time of release of the aortic clamp are: acidosis, citrate intoxication, potassium intoxication, hypothermia of the heart due to cold blood and blood loss from the anastomosis. These factors are also of major concern in the cases of ruptured aneurysms requiring resuscitation prior to surgery. This whole field of cardiac sollapse associated with the massive transfusion of citrated blood has recently been reviewed by Gain. ${ }^{2 \tau}$

Cooper and Ross ${ }^{26}$ state that the blood returning from the anoxic tissues has a low $\mathrm{pH}$ and a high serum $\mathrm{K}+, \mathrm{PO}_{4}=$, and lactic acid level. It would tend then to contribute to any problems or difficulties resulting from acidosis or hyperkalaemia. That a metabolic acidosis of considerable degree does result from cross-clamping of the aorta has been shown by Rader et al. ${ }^{28}$ experimentally in dogs. Blood stored in an acid-citrate-dextrose mixture has, after a few days, a low $\mathrm{pH}$ (about 6.5) and high lactic acid concentration due to glycolysis. A rapid infusion of stored blood can produce an acute and significant $\mathrm{pH}$ stress. ${ }^{26}$

Bunker et al. ${ }^{29}$ have recently demonstrated for the first time in man that with rapid transfusion ( 500 c.c. q. $3-4$ minutes in a $70-\mathrm{kg}$. man) citrate alone can produce moderate to severe cardiac depression (serum lactate levels of $50-75$ mg./100 c.c.). Calcium chloride, digitalis, and to a lesser degree epinephrine protect the heart against citrate intoxication. They suggest that the patient with poor cardiac function or the patient in hacmorrhagic shock may exhibit less tolerance to high citrate levels and that the effects of other factors, such as hyperkalaemia, acidosis, and anaesthesia, may share with citric acid an additive effect in the aetiology of circulatory disaster.

Prior to this convincing evidence, there was some doubt as to the significance of the fact that citrate diminishes the level of ionized calcium and hence depresses cardiac muscle function. A haemorrhagic diathesis from decreased calcium level is generally accepted as very unlikely. ${ }^{27}$ In hypothermia, citrate metabolism is 
reduced, probably by about 40 per cent at $28.5^{\circ} \mathrm{C} .{ }^{26}$ and the rate of blood transfusion should not exceed 500 c.c. in 10 minutes.

The exact role of hyperkalaemia is very much undecided and no real clinical guides are available. ${ }^{27}$ One school maintains that hyperkalaemia is a danger in surgery and in shock, and an opposing group feels that the amounts of $\mathrm{K}^{+}$ion in bank blood are insufficient to produce cardiac arrest even at 500 c.c. per 5 minutes.

Boyan and Howland ${ }^{30}$ recently reported on inadvertent hypothermia caused by the massive transfusion of cold blood, having studied several cardiac arrests which they felt could only be attributed to this cause. They found usually less than $1.5^{\circ} \mathrm{C}$. change in oesophageal temperature until after $i, 800$ c.c. Was given, but thereafter an almost linear drop in temperature occurred, terminating in ventricular fibrillation and the other effects of hypothermia. They considered that the other deleterious effects of massive transfusion may be augmented by the hypothermia, especially in the presence of acidosis, hypercarbia, and hypoxia which may exist coincidentally with hypotension.

Blood loss from the anastomosis, similar to many other factors involving surgical technique ${ }^{6}{ }^{31}$ is less of a problem with increased experience of both surgical and anaesthetic teams. The presence of an arteriosclerotic, non-pliable vessel wall at the site of the anastomosis can be an insurmountable hazard.

\section{(b) Problems of Postoperative Depression of Renal Function}

Acute renal failure is a severe complication of abdominal aortic surgery: Powers $e t a l^{32}$ reported that oliguria occurred for the first few postoperative days in 30 per cent of their series, that azotaemia occurred in 20 per cent, and that in a one-year period four deaths occurred with distal tubular necrosis as the principal or contributing cause. Whitley et al. ${ }^{33}$ referred to it as a "major complication." Doolan et al. ${ }^{34}$ reported on 11 cases with 5 deaths. In the Mayo Clinic report ${ }^{12} 20$ per cent of the deaths from elective aneurysmectomies were due to acute renal failure.

In our series, oliguria was present in some degree in 35 per cent of all cases surviving operation (Table VI) but it does not appear to be an important cause of death (Table VII), exceptions being two cases of renal infarction-one in a case with Leriche syndrome and one in a case with ruptured normothermia aneurysm requiring clamping of both renal arteries.

There is some disagreement in recent reports as to the mechanism of this renal insufficiency and as to prophylactic measures. Current concepts of aetiology are: atheromatous embolization, ischaemia due to low blood volume, ischaemia due to some reflex or humoral mechanism unique to cross-clamping of the abdominal aorta ${ }_{2}^{34.35,36} 37$ blood transfusion accidents, "sludging" due to the large number of transfusions, or a combination of these factors.

One of our normothermic cases demonstrated clearly that oliguria of a severe degree-an also result simply from dehydration and electrolyte disturbance in the apparent absence of renal damage. This 73-year-old patient with a ruptured aneurysm did not develop hypotension of less than $60 \mathrm{~mm}$. Hg during the operation but his postoperative daily urine outputs of $450,415,392$, and 260 c.c. caused considerable concern until a hyponatraemia and hypokalaemia secondary to 
paralytic ileus was corrected. He excreted 600 c.c. on the fourth and 1,122 c.c. on the seventh postoperative day, at which time his B.U.N. was $65 \mathrm{mg}$. per cent.

That atheromatous emboli to the renal arteries after aortic surgery is a real entity and one of considerable importance, at least in some cases, has been clearly proved by Thurlbeck and Castleman, ${ }^{35}$ who demonstrated acute emboli of atheromatous material in the kidneys of 17 of their 22 patients (77.3\%) dying after surgery for aneurysm or arteriosclerosis of the abdominal aorta. Four of these patients had multiple renal emboli and died in uraemia, and in four others (18\%) with a comparable degree of embolization, death could be ascribed to other causes, but the emboli probably were important contributory factors.

Treatment of the postoperative oliguria consists of the usual measures, including dialysis, ${ }^{35}$ but the significant recent recormmendations are prophylactic. Ganglionic blockade (with Arfonad, or Phenoxybenzamine), infiltration of the renal pedicle (with local anaesthetic), papaverine, and trasentine have been used to prevent renal vasoconstriction. ${ }^{32,33,34}$

The most interesting recent prophylactic measure is the use of Mannitol by Barry et al. ${ }^{\mathbf{3 9 , 4 0 , 4 1}}$ This drug, an old experimental tool in physiology, is a 6-carbon hexahydric alcohol. It is distributed slowly in the cxtracellular fluid, freely filtered at the golmerulus, and is not reabsorbed. Inert and non-toxic, it is the most effective renal osmotic solute available. It is felt that since Mannitol is held in the tubular lumen it may cause an increase in fluid volume discouraging tubular collapse. There may be a local increase of nutrients necessary for renal tissue metabolism, which protects the kidney during suissequent decreased renal blood flow caused by cross-clamping of the abdominal aurta.

\section{(c) Problems Associated with Hypothermia}

The complications of induced hypothermia are well reviewed by Smith ${ }^{17}$ and. Little. ${ }^{20}$ Those occurring in our patients were arrhythmias, one cardiac arrest, an increased incidence of respiratory disease, hypotension postoperatively, and an increased blood loss.

If for the hypothermia cases a lower limit of $30^{\circ} \mathrm{C} .\left(86^{\circ} \mathrm{F}\right.$.) is chosen, one might expect that cases cooled below this level would exhibit a greater mortality and mbrbidity. Our data were examined with this thought in mind, but the two groups were roughly comparable, possibly owing to the small numbers of cases and the many other factors involved. Indeed, it may be that a mild degree of hypothermia occurred in many of our "normothermia" cases.

The only comparable study found in the recent literature is that of McKissock and Taylor ${ }^{42}$ who found in a study of supratentorial meningiomas no significant difference in mortality or morbidity between cases done under hypothermia and similar cases done under normothermia.

\section{SUMMARY}

A retrospective analysis was made of 113 operations involving clamping of the abdominal aorta for aneurysms or thrombosis and the results of 54 operations under induced hypothermia are compared with $\$ 9$ operations under ordinary operating room conditions. The two groups are shown to be comparable as to 
age and sex distribution. Similar surgical and anaesthetic techniques were used. Supportive blood transfusions, used in every case, averaged 500 c.c. more in the hypothermia group. Only 3 cases in the hypothermia group were cooled to less than the recommended $27^{\circ} \mathrm{C}$. $\left(81^{\circ} \mathrm{F}\right.$.). Cardiac arrhythmias were recorded in 7 hypothermia patients and 1 normothermia patient. One cardiac arrest occurred in the hypothermia group.

Complications occurring during the hospital stay were comparable except for an increased incidence of prolonged postoperative hypotension and of pulmonary complications in the hypothermia group. There was no proof of a protective effect of hypothermia in respect to the incidence of oliguria, and in all the cases, serious oliguria was uncommon. The death rates were comparable except for those with ruptured aneurysms, both operative and late deaths being higher in the normothermia group. An attempt has been made to explain this difference.

Consideration is given as to the use of hypothermia in other centres and to the pertinent literature regarding anaesthetic problems encountered in these challenging operative procedures. Factors associated with hypotension are reviewed as well as those relating to postoperative depression of renal function.

Considering the lack of convincing benefit in our series, the known untoward effects, and the available evidence that it is not beneficial in inaemorrhagic shock, it is recommended that induced hypothermia not be used in operations requiring cross-clamping of the abdominal aorta below the renal arteries and that Mannitol should be seriously considered in doses adjusted to measured urine output. Hypothermia is felt to have a place if occlusion of the renal arteries is contemplated.

The oesophageal temperature should be monitored and $\mid \mathrm{a}$ warming blanket used in instances of inadvertent hypothermia of less than $32^{\circ} \mathrm{C}$. $\left(90^{\circ} \mathrm{F}\right.$.). The use of pneumatic tourniquets on the upper thighs should be considered for control of blood flow to the legs at the critical time of release of the aortic clamps.

\section{RÉSUMÉ}

Nous avons fait une analyse rétrospective de 113 opérations au cours desquelles l'aorte abdominale avait été pincée, et nous avons comparé les résultats de 54 opérations exécutées sous hypothermie et 59 sans hypothermie. Les deux groupes se sont avérés comparables en ce qui concerne lâge et le sexe. Nous avons employé des agents et des techniques anesthésiques semblables. Aux malades hypothermisés, nỡus avons donné 500 c.c. de sang de plus qu'aux autres. Seulement chez trois de ces malades, la $T^{\circ}$ a été abaissée au-dessous de la température recommandée de $27^{\circ} \mathrm{C}$. ( $81^{\circ} \mathrm{F}$.). On a observé des arythmies cardiaques chez 7 malades sous hypothermie et chez un seul sans hypothermie. Un arrêt cardiaque est survenu chez les hypothermisés.

Au cours de séjour à l'hôpital, le nombre des complications est comparable à part les complications pulmonaires et l'hypotension prolongée chez les hypothermisés. Rien ne prouve que l'hypothermie ait été une protection contre la fréquence de l'oligurie et, dans l'ensemble, nous n'avons pas observé d'oligurie marquée. Les taux de mortalité sont comparables, excepté pour les cas d'anévrysme rupturé où les morts opératoires et les morts tardives ont été plus 
nombreuses dans le groupe sans hypothermie. Nous avons essayé d'expliquer cette différence.

Nous commentons l'usage de l'hypothermie dans les autres centres et dans la littérature sur les problèmes anesthésiques posés par ces audacieuses entreprises chirurgicales. Nous avons analysé les facteurs ass(xciés à l'hypotension ainsi que ceux associés à la dépression postopératoire de la fonction rénale.

Dans notre série, en face de l'absence d'avantages manifestes, comnaissant les effets malencontreux de l'hypothermie et sachant qu'elle n'est d'aucun secours dans le choc hémorragique, nous conseillons de ne pas employer l'hypothermie au cours des opérations où il faudra pincer l'aorte abdominale au-dessous des artères rénales et de doser le mannitol selon le débit urinaire. L'hypothermie semblerait avoir une place si l'on pense que les artères rénales sont bloquées.

La température oesophagienne doit être enregistrée et nous conseillons l'usage d'une couverture chauffée au cas où, par inadvertance, l'hypothermie dépasserait $32^{\circ} \mathrm{C}$. $\left(90^{\circ} \mathrm{F}\right.$.). L'usage de tourniquets pneumatiques placés à la partie haute des cuisses est à retenir pour contrôler le débit sanguin dans les jambes au moment d'enlever la pince sur l'aorte.

\section{REFERENCES}

1. McKenzie, A. D. Abdominal Aortic Aneurysms-1ntact and Ruptured. Am. I Surg. 100: 176 (1960).

2. Elliot, J. A.; McKenzie, A. D.; \& Chung, W. B. Ruptured Abdominal Aortic Aneurysm. Surgery 46: 605 ( 1959 ).

3. Thornton, H. L. Anaesthesia for Aortic Reconstruction. Brit. Med. J. 1: 253 ( 1957 ).

4. Wylte, W. D. \& Churchinl-Davinson, H. C. A Practise of Anaestheisa. Chicago: The Year Book Publishers, Inc. (1961).

5. Crawford, E. S.; DeBakey, M. E.; Coolex, D. A.; \& Morris, G. C. Surgical Considerations of Aneurysms and Athero-sclerotic Occlusive Lesions of the Aorta and Major Arteries. Postgrad. Med. 29: 151 (1961).

6. DeBakey, M. E.; Coolex, D. A.; \& Creech, D. Aneurysm of Aorta Treated by Resection. J.A.M.A. 163: 1439 (1957).

7. Swan, H. \& Paton, B. C. The Current Status of Hypothermia in Cardiovascular Surgery: Prog. Cardiovas. Dis. 4: 228 (1961).

8. Eiseman, B.; Owens, J. D.; \& Swan, H. Hypothermia in General Surgery, New Engl. J. Med. 255: 750 (1956).

9. Gryska, P. F.; Wheeler, C. G.; \& Linton, R. R. A Review of Seven Years Experience with Excision and Graft Replacement in 150 Ruptured and Unruptured Aneurysms of the Abdominal Aorta. New Engl. J. Med. 264: 639 (1961).

10. DeWeese, M. S. \& Fry, W. J. Pitfalls in Surgery of the Abdominal Aorta. Surg. Clin. North America 41: 1331 (1961).

11. Moore, S. W. \& Wantz, G. Abdominal Aortic Aneurysm. Surg. Clin. North America 41: 497 (1961).

12. Sheranian, L. O.; Edwards, J. E.; \& Kinklin, J. W. Late Results in 110 Patients with Abdominal Aortic Aneurysm Treated by Resection Replacement of Aortic Homograft. Surg. Gynec. \& Obst. 109: 309 (1959).

13. Gwathmey, P.; Puenpont, H. C.; \& Blades, B. Clinical Experiences with the Surgical Treatment of Acquired Aortic Vascular Diseases. Surg Gynec. \& Obst. 107: 205 (1958).

14. Albert, S. N.; Spencer, W. A.; Boling, J. C.; \& Thistlethwatte, J. R. Hypothermia in the Management of the Poor-risk Patient Undergoing Major Surgery. J.A.M.A. 163: 1435 (1957).

15. Bigelow, W. G. Hypothermia. Surgery 43: 683 (1958).

16. Potts, W. J.; Tatsoles, C. J.; Ketola, F. H.; \& BłFFes, 'T. G. Induced Hypothermia. in General Surgery. Surgery 51: 724 (1962). 
17. Smith, R. M. \& Stetson, J. B. Therapeutic Hypothermial. New Engl. J. Med. 265! 1097 and 1147 (1961).

18. Lucas, B. G. B. Hypothermia in Surgery: The Present Position. Brit. Med. Bull. 14: 46 (1958).

19. Lewrs, F. J. Hypothermia-Physiology and Clinical Applicationb. Surg: Clin. North America 42: 69 (1962).

20. Littile, D. M: Hypothermia. Anesthesiology 20: 842 (1959).

21. Stephen, C. R. \& Dent, S. J. Applications of Hypothermia in Nedical Practise. Am. Surgeon 28: 32 (1962).

22. MacPheE, I. W.; Gray, T. C.; \& Davies, S. Effect of Hypothemia on the Adrenocortical Response to Operation. Lancet ii, 1196 (1958).

23. Wilson, J. N.; Marshall, S. B.; Beresford, V.; Montgoniery. V.; Ienkins, D.; \& Swan, H. Experimental Haemorrhage: The Deleterious Effect of Hlypothermia on Survival and a Comparative Evaluation of Plasma Volume Changes. Ann Surg. 144. 696 (1956).

24. Ferguson, A. T.; Wilson, J. N.; Jenkins, D.; \& Swan, H. Effedt of Hypothermia on Haemorrhagic Shock. Ann. Surg. 147: 281 (1958).

25. Simti, G.; Lawson, D.; \& Penhale, B. Effect of Hypothermid on Acute Coronary Occlusion. Brit. J. Surg. 44: 419 (1957).

26. Cooper, K. E. \& Ross, D. N. Hypothermia in Surgical Practicè. London: Cassell \& Co. Ltd. (1960).

27. GaIn, E. S. The Problem of Cardiac Collapse Associated with the Massive Transfusion of Citrated Blood. Canad. Ana'esth. Soc. J. 9: 207 (1962).

28. Rader, L. E.; Kerth, H. B.; \& Canipbell, G. S. Mechanism of Hypotension Following Release of Abdominal Aortic Clamps. Surg. Forum XII: 265 (1961).

29. Bunker, J. P.; Bendixen, H. H.; \& Murphy, A. J. The Hemodynamic Effects of Intravenously Administered Sodium Citrate. New Engl. J. Med. 266: 372 (1962).

30. Boyan, C. P. \& Howland, W. S. Blood Temperature: A Critical Factor in Massive Transfusion. Anesthesiology 22: 559 (1961).

31. Martin, P. Some Difficulties and Early Complications of Operatipns on the Abdominal Aorta below the Renal Arteries. Brit. J. Surg. 48: 530 (1961).

32. Powers, S. A.; Boba, A.; \& Stein, A. The Mechanism and Prevention of Distal Tubular Necrosis Following Aneurysmectomy. Surgery 42: 156 (1957).

33. Whitley, J. E; Witcofski, R. L.; Felts, J. H.; \& Meschan, I. The Investigations of Renal Complications of Aortic Clamping. Surgery 50:673 (1961).

34. Doolan, P. D.; Wiggins, R. A.; Thiel, G. B.; LeE, K. J.; \& Martinez, E. Acute Renal Insufficiency Following Aortic Surgery. A Discussion of the Pathogenesis and a Consideration of Gangrene of an Extremity as a Complication. Am. J. Med. 28: 895 (1960).

35. Thurlbeck, W. M. \& Castleman, B. Atheromatous Emboli to the Kidneys after Aortic Surgery. New Engl. J. Med. 257: 442 (1957).

36. Nanson, E. M.; Noble, J. G.; \& Emson, H. The Effect on the Kidneys of Cross Clamping the Aorta Distal to the Renal Arteries. Surg. Forum IX: 347 (1958).

37. Barky, W. B.; Monris, G. C.; \& DeBakeY, M. E. Alterations in Renal Haemodynamics during Surgical Resection of Abdominal Aortic Aneurysms. Clin. Res. 7: 163 (1959).

38. HinnRerG, J.; Nakamoto, S.; \& Kolff, W. J. Anuria after Operations for Abdominal Aortic Aneuryesm Treated by Hemodialysis with Complete Recovery. Surgery 50: 755 (1961).

39. Barry, K. G.; Cohen, A.; \& Leblanc, P. Mannitolization I. The Prevention and Therapy of Oliguria Associated with Cross-Clamping of the Abdominal Aorta. Surgery 50: 335 (1961).

40. Barry, K. G.; Cohen, A.; Knochel, J. P.; Whelan, T. J.; Beisel, W, R.; Vargos, C. A.; \& Leblanc, P. C. Mannitol Infusion II. The Prevention of Acute Functional Renal Failure during Resection of an Aneurysm of the Abdominal Aorta. New Engl. J. Med. 264: 967 (1961).

41. Barky, K. G. \& Berman, A. R. Mannitol Infusion III. The Acute Effect of the Intravenous Infusion of Mannitol on Blood and Plasma Volumes. New Engl. J. Med. 264: 1085 (1961).

42. McKissock, W. \& TAYLOR, J. C. A Comparison of Supratentorial Intracranial Meningiomas Operated Upon with and without Induced Hypothermia. Brit. J. Surg. 48: 155 $(1960)$. 